\title{
Minutes of the 19th General Assembly of the European Association for the Study of Diabetes
}

\author{
Held in the House of Engineers, University of Oslo, Norway, \\ on Friday, 16 September 1983 at 5.45 p. m.
}

Present:

Dr. W. Gepts (President)

Dr. H. M.J. Krans (Honorary Treasurer)

Dr. K.G.M.M. Alberti (Honorary Secretary)

Dr. M. Berger (Editor-in-Chief, Diabetologia)

Dr. D. Andreani (President-Elect)

and 189 members

Before proceeding to the agenda, the President reminded the General Assembly of the death in October 1982 of Professor Andrew Cudworth, Editor-in-Chief of Diabetologia, and invited the membership to stand in silence in his memory and in memory of other distinguished colleagues who had died during the year.

\section{Minutes. 18th General Assembly, 1982}

The Minutes of the 18th General Assembly held in Budapest, Hungary, had been printed in both the Volume of Abstracts which participants had received on registration, and also in Diabetologia, Volume 25, Number 2, 1983. The General Assembly agreed that they should be taken as read. The file copy was signed by the President and Honoarary Secretary as a correct record.

\section{Reports}

President: In his opening remarks, the President recalled the 18 th Annual Meeting in Budapest, and expressed the Association's thanks to Professor Magyar, Dr. Tamas and their colleagues on the Organising Committee for all that they had achieved in providing a memorable meeting.

Continuing, Dr. Gepts paid tribute to the excellent arrangements which had been made by Professor Walaas, Dr. Jervell and their colleagues for the present 19th Annual Meeting in Oslo. The meeting had established another precedent, in that there were now five simultaneous sessions, which was perhaps an indication of the good health of the Association from the scientific point of view since the selection of abstracts proved so difficult for the Programme Committee. However as other Officers would be reporting, there were darker clouds on the horizon.

The President expressed the Association's sincere thanks to Drs Nattrass, Tattersall, Malaisse and Alberti for the work which they had undertaken to keep Diabetologia going during Andrew Cudworth's last illness, and in the interim period following his death; and welcomed Dr. Michael Berger to the heavy responsibilities of Editor-inChief. Continuing, Dr. Gepts said that the high standard of the journal owed much to the considerable contribution made by the Editorial Assistant, Mrs. Sarah Spencer-Smith.

Continuing, the President expressed the thanks of the Association to the pharmaceutical industry in general for their assistance, both as Supporting Members and also in the Trade Exhibition, which he urged members to visit. The Association was especially grateful to Novo Industri for their continued provision of generous subventions for Travel Grants and for the Volume of Abstracts; to Pfizer-Europe for their repeated grant for additional Travel Awards; to Hoechst AG for their sponsorship of the annual Minkowski Prize; and to the Laboratoires Paul Neumann for their sponsorship of the Claude Bernard Lecture. To warm applause, the President announced that the 1984 Claude Bernard Lecture would be given by Professor Pierre Lefèbvre.
Honorary Treasurer: Dr. Krans introduced the annual accounts for the year ended 31 December, 1982.

Income

$£^{\frac{1982}{}} £ £^{\frac{1981}{}} £$

Subscriptions:

Active members

Supporting and associate

members

Donations

Other income

EASD Travel Fund:

Novo Industri A/S Grant

Pfizer-Europe grant

Other income

EASD Annual Meetings Fund: Surplus: 1981 Meeting

Surplus: 1982 Meeting

Other income

Expenditure

Administrative:

Salaries

Pension contribution

Rent

Post, telephone and stationery

Audit fee

Executive Committee Meeting

Bank charges

Diabetologia: editorial office

Annual meeting: secretariat

Triennial membership list

EASD travel grants

Allocation; annual meeting expenses

Surplus for year:

EASD travel Fund

$16,892 \quad 13,438$

7,603

$\underline{5,097}$

ASD Annual Meetings Fund

Accumulated General Fund

$$
\begin{aligned}
& 8,770 \quad 8,081 \\
& \begin{array}{rr}
750 & 750 \\
1,250 & 1,250
\end{array} \\
& 2,834 \quad 2,469 \\
& 185 \quad 175 \\
& 376 \quad 922 \\
& \begin{array}{rr}
48 & 26 \\
4,707 & 5,805
\end{array} \\
& 3,812 \quad 7,106 \\
& 940
\end{aligned}
$$

Balance sheet as at 31 December 1982

Accumulated General Fund:

$$
\begin{aligned}
& \text { Balance at } 1 \text { January } 1982 \\
& \text { ADD: Difference on conversion } \\
& \text { ADD (Less): Surplus for year } \\
& \text { Transfer from Annual Meetings } \\
& \text { Fund }
\end{aligned}
$$

carried forward 
rought forward

ASD Travel Fund:

ADD (Less): Surplus for year

EASD Annual Meetings Fund:

Balance at 1 January, 1982

ADD: Surplus for year

Transfer to Accumulated General Fund

Subscriptions received in advance:

Active members

Journals

Provision for loss on exchange

Represented by:

CASH at banks and in hand

London

Geneva

ADD: Sundry debtors

LESS: Sundry creditors
Balance at 1 January 1982

18,932
4,725

$\underline{917}$

$$
5,642
$$

5,148

(423)

4,000
3,415

$\frac{3,415}{7,415}$

4,000

9,282

7,415

13,282

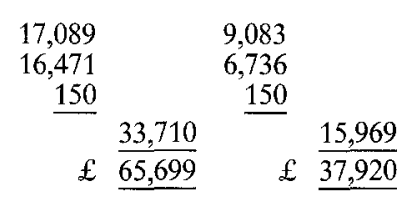

$\begin{array}{r}38,306 \\ 17,418 \\ \hline 55,724 \\ 15,821 \\ \hline 71,545 \\ (5,846) \\ \hline\end{array}$

20,918

11,330

$\overline{32,248}$

14,985

$\overline{47,233}$

$(5,846)$
4,000

4,725

$\overline{37,920}$
$7,415^{(9,282)}$

There had been a welcome increase in income of $£ 3,500$, mainly due to the increase in annual subscriptions, but also thanks to increased funding from Supporting Members. In addition the Association had received a surplus from the Budapest meeting, and an additional transfer of surplus funds from the 1981 meeting in Amsterdam. Expenditure had in fact decreased, despite natural increases in basic administrative costs. The main savings related to the lower number of papers accepted for publication in the Volume of Abstracts, and an increase in the subvention donated by Novo Industri for this purpose. Thus the Balance Sheet showed what appeared to be a very healthy state, but the Honorary Treasurer regretted to report that this was unlikely to continue in the same way in the future.

Continuing, Dr. Krans said that a Review Committee appointed by the Council in the previous year to look into the office administration had made three recommendations which would have a major impact on the Association's financial resources. The first recommendation was for the purchase of a microcomputer to assist in the increasingly complex task of handling the growing membership. The capital expenditure involved was $£ 7,000$ which had been allocated from the Accumulated General Funds. The microcomputer had now been installed, and the Executive Committee anticipated that when fully operational it would greatly help in the administration of the Association without increasing the staffing requirement.

The second recommendation which had important implications on expenditure related to office administration. For many years, the Association had been able to enjoy the benefit of efficient service at a relatively low cost because it had been able to share its activities within one office with other organisations. One of the findings of the Review Committee was that because of the growth of membership over the years the time expended by the Executive Director on EASD business now amounted to about $50 \%$ of his time, whereas only about $25 \%$ of his salary and pension contribution were currently charged to the Association. The Executive Committee therefore recommended to the Council, which in turn had accepted it, that in future the Association should meet the full costs of proper administration.

The third recommendation made by the Review Committee was that the Editorial Office of Diabetologia should be moved to the London Secretariat offices, and this move had now been effected. The acceptance of the post of Editor-in-Chief by Dr. Michael Berger had meant the creation of an additional editorial office in Düsseldorf, which had widespread consequences, not the least of which concerned the appointment of Mrs. Sarah Spencer-Smith as Editorial Assistant, with a consequent up-grading in her salary, and the introduction of a pension scheme arrangement for her. These arrangements had been put into effect, but Dr. Krans was happy to report that as a result of the excellent efforts of Dr. Berger in securing more advertising for the journal, Springer Verlag were currently looking into the whole question of the financial arrangements relating to the journal. However, pending the results of these negotiations, and taking into account the expenditure indicated under the three recommendations,
Dr. Krans believed it likely that the increases in annual costs could amount to some $£ 12,000$ per year, and it was for that reason that he would later be proposing increases in annual subscriptions for all categories of membership.

In conclusion, the Honorary Treasurer assured the General Assembly that every effort was being made to minimise the effect of these increased costs, and moved that the annual accounts for 1982 be accepted.

Honorary Auditors: Dr. Serrano-Ríos, on behalf of Dr. E. Standl and himself, confirmed that the accounts were in good order and discharged the Honorary Treasurer from responsibility for the accounts for the year ended 31 December 1982.

Honorary Secretary: Dr. K.G. M. M. Alberti reported that there had been a net fall in membership of 92 , so that the membership at the end of 1982 was 1,547 , distributed as shown in Table 1 . There had been 138 enrolments, and 21 former members had rejoined. Against this, 236 members had failed to renew their subscriptions, and 15 members had died or resigned.

Table 1. EASD membership at 31 December 1982 (1981 comparisons on left)

\begin{tabular}{|c|c|c|c|c|c|}
\hline 1981 & & 1982 & 1981 & & 1982 \\
\hline 1 & Algeria & 1 & 871 & b/forward & $\overline{841}$ \\
\hline 3 & Argentina & 3 & 1 & Kuwait & 1 \\
\hline 26 & Australia & 27 & 3 & Lebanon & 1 \\
\hline 20 & Austria & 18 & 1 & Luxembourg & 1 \\
\hline 1 & Bangladesh & 1 & 1 & Malta & - \\
\hline 81 & Belgium & 81 & 74 & Netherlands & 70 \\
\hline 1 & Brazil & - & 3 & New Zealand & 1 \\
\hline 13 & Bulgaria & 13 & 1 & Nigeria & 1 \\
\hline 12 & Canada & 10 & 18 & Norway & 13 \\
\hline 38 & Czechoslovakia & 38 & 1 & Papua New Guinea & - \\
\hline 2 & Cyprus & 2 & 15 & Poland & 15 \\
\hline 130 & Denmark & 114 & 17 & Portugal & 17 \\
\hline 1 & Dominican Republic & c 1 & 22 & Ror & 22 \\
\hline 3 & Egypt & 2 & 3 & Saudi Arabia & 4 \\
\hline 28 & Finland & 30 & 2 & South Africa & 1 \\
\hline 114 & Franc & 104 & 44 & Spain & 41 \\
\hline 34 & Germany, East & 34 & 93 & Sweden & 84 \\
\hline 134 & Germany, West & 126 & 76 & Switzerland & 70 \\
\hline 17 & Greece & 17 & 1 & Thailand & 1 \\
\hline 24 & Hunga & 25 & 7 & Turkey & 8 \\
\hline 1 & India & 2 & 299 & United Kingdom & 271 \\
\hline 1 & Iraq & 1 & 68 & United States & 68 \\
\hline 31 & Israel & 26 & 2 & Venezuela & 1 \\
\hline 146 & Italy & 155 & 13 & Yugoslavia & 15 \\
\hline 9 & Japan & 10 & 3 & Zaire & - \\
\hline 871 & carried forward & 841 & 1639 & total & 1547 \\
\hline
\end{tabular}

Turning to the arrangements for the current meeting, Dr. Alberti reported that 639 abstracts had been received, an increase of 102 over those for Budapest. With some difficulty, the Programme Committee had been able to accept $424(66 \%)$ for oral or poster presentation by increasing the number of simultaneous sessions to five. The Honorary Secretary emphasised that rejection of an abstract did not imply any criticism of the methodology or content of the paper, but merely the age-old problem of trying to fit a quart into a pint bottle. If there was some ethical reason for rejection this would be communicated to the author. But the Programme Committee, to whom Dr. Alberti paid tribute for their valued help, had to take into account not only the quality of the submissions, but also the overall pattern of the programme. Continuing, the Honorary Secretary said that these comments also applied to the question of publication of abstracts. The Council had endorsed the recommendation that only those accepted for oral or poster presentation be accepted.

Dr. Alberti drew attention to the publication of the Minutes of the Budapest General Assembly in the Volume of Abstracts for the first time, to make them more easily available to those members who did not subscribe to the journal.

The Honorary Secretary then reported that thanks to an increased subvention from Novo Industri and the repeated support from PfizerEurope, coupled with a much larger than usual allocation from the EASD Travel Fund, the Association had been able to award travel grants to 72 young colleagues under the age of 35 who were pre- 
senting papers in the meeting. The cost involved was $£ 9,000$, compared with $£ 6,150$ in 1982.

Dr. Alberti referred to the recommendations made by the Review Committee already reported by the Honorary Treasurer, and paid tribute to the help received from Dr. Simon Walford in installing the microcomputer. Until the "sort" programmes had become fully operational it would be important for members to know their membership numbers and to quote them on all correspondence. One of the advantages of the new technology was that record-keeping was made considerably easier, and this had already resulted in the discovery that a number of individuals were subscribing to the various journals for which preferential rates had been negotiated but were not in fact paidup members of the Association. It was clearly unfair to other members to take advantage of the special rates and not to support the Association, and Dr. Alberti appealed to any members whose consciences were troubling them to take the necessary steps and re-join the Association.

Continuing, Dr. Alberti drew the attention of members to the fact that the American Diabetes Association had recently sent reminders direct to subscribers to the journals Diabetes and Diabetes Care whose subscriptions expired at the end of 1983. If members renewed direct to the $A D A$ as requested, they would lose the $25 \%$ discount available to $E A S D$ members. In order to claim the preferential rates, orders for journals must be placed through the London Secretariat. The Honorary Secretary said that he could well understand the frustration which many members had experienced in their dealings with the ADA, but wished to assure the General Assembly that the cause was seldom that of the London office.

Dr. Alberti then drew attention to the fact that less than $20 \%$ of the total membership presently subscribed to the journal of the Association, Diabetologia, and urged more members to take advantage of the generous discount of $50 \%$ which had been negotiated on their behalf.

Turning to arrangements for future meetings, the Honorary Secretary announced that selection of abstracts would in future be made anonymously. This would necessitate some variation of the forms presently used and Dr. Alberti urged the membership to read carefully the printed instructions which would be included in the preliminary booklet for the next meeting. The closing date for abstracts would be 15 April 1984. The closing date for nominations for the Minkowski Prize would be 1 February 1984.

In conclusion, the Honorary Secretary announced the dates of future Annual Meetings as follows:

1984 Barbican Centre, London, UK: 12-15 September

1985 Madrid, Spain: 23-28 September (12 IDF Congress)

1986 Rome, Italy: 10-13 September

The President thanked Dr. Alberti for his report.

Editor-in-Chief. Diabetologia: Dr. Berger reminded the General Assembly that Diabetologia had been started by Prof. Oberdisse from Düsseldorf in 1965. From there, it had moved sideways to Göttingen and Frankfurt (1973-1976), and had then gone to England, to Southampton, Newcastle upon Tyne, and thence to London (1977-1982), and now had returned to Düsseldorf.

Dr. Berger thanked Drs. K.G.M.M. Alberti, R. B. Tattersall and M. Nattrass and Mrs. Sarah Spencer-Smith for all the time and effort they had put in on behalf of the journal during the winter of 1982-1983.

Continuing, the Editor-in-Chief then reported that as from 1 March 1983, there were two offices. The Records Office in London was run by Mrs. Spencer-Smith and had five British Assistant Editors responsible for language editing. This office had recently moved to 10, Queen Anne Street from St. Bartholomew's Hospital. The other office was in Düsseldorf under his control, with two Assistant Editors and Mrs. Beverly Niemann as secretary. The main reason for having dual offices was that the London office would form a permanent base for all journal records, and consequently it would prove less cumbersome to move the office of the Editor-in-Chief as the office rotated. It would also help to ensure continuity during change-overs. Dr. Berger reminded the General Assembly that there were two Deputy Editorsin-Chief, Dr. R.B. Tattersall (Nottingham), and Dr. W.J. Malaisse (Brussels), and 13 Associate Editors at various outposts around Europe.

Efforts were being made to avoid the problems of split offices, and Dr. Berger believed that they had been able to speed up the publication process. As he saw them, the principle problems were speed, double publication and authors disagreeing about the submission of manuscripts. At the meeting of the Editorial Board held in Oslo, it had been decided to institute a policy that submissions must be accompa- nied by a letter signed by all authors stating that the work had not been published before, had not been submitted for publication elsewhere, and authorising the submission of the manuscript to Diabetologia. Two papers had been withdrawn because authors did not agree, and this caused much extra and unnecessary work for the editorial staff.

Turning to the development of the journal, the Editor-in-Chief stated that the submission rate had plateaued at around 400 for each of the past 3 years (1980-1982), but the anticipated numbers of papers submitted for 1983 was 500 . The percentage acceptance rate had been falling since $1979(50 \%)$ to around $35 \%$ in 1983 . Of the 162 papers published in 1982, 65\% were from Europe (UK 27\%), 16\% from North America and 14\% from Australia. Table 2 gives the accepted papers for 1982.

Table 2.

\begin{tabular}{llllll}
\hline Country & \multicolumn{2}{l}{$\begin{array}{l}\text { Ratio accepted } \\
\text { rejected } \\
\text { manuscripts }\end{array}$} & $\begin{array}{l}\text { Manuscripts } \\
\text { accepted } \\
\text { (total 162) }\end{array}$ & $\begin{array}{l}\text { Number of } \\
\text { reviewers } \\
\text { (total 774) }\end{array}$ \\
\cline { 2 - 4 } & 1980 & 1981 & 1982 & & \\
\hline UK & 0.7 & 1.7 & 1.1 & 43 & 333 \\
USA & 0.5 & 0.9 & 0.6 & 24 & 171 \\
Denmark & 1.9 & 1.4 & 0.9 & 14 & 76 \\
Japan & 0.5 & 0.3 & 0.6 & 11 & 1 \\
Australia & $0 / 13$ & 3.0 & 1.6 & 11 & 16 \\
Sweden & 0.7 & 0.8 & 0.6 & 9 & 21 \\
France & 1.0 & 1.0 & 0.7 & 8 & 18 \\
Italy & 0.1 & 0.6 & 0.4 & 6 & 19 \\
Belgium & 3.5 & 1.0 & 1.7 & 5 & 21 \\
West Germany & 0.6 & 1.4 & 0.4 & 5 & 29 \\
\hline
\end{tabular}

When the number of accepted papers was considered per million population, a different picture emerged (Table 3 ).

Table 3. Number of accepted papers per million population

\begin{tabular}{ll}
\hline Denmark & 2.80 \\
Sweden & 1.13 \\
Australia & 0.92 \\
United Kingdom & 0.84 \\
Austria & 0.57 \\
Belgium & 0.55 \\
Israel & 0.42 \\
France & 0.16 \\
USA & 0.13 \\
Italy & 0.12 \\
East Germany & 0.12 \\
Japan & 0.11 \\
West Germany & 0.09 \\
\hline
\end{tabular}

Dr. Berger then reported with much pleasure that Springer Verlag had agreed to maintain the annual subscription rate for the journal for 1984 at the same rate as for 1983: and furthermore, he was happy to report that as from 1 January 1984, Springer would pay all running costs of the journal, thus relieving the Association of this responsibility and expense.

Following the decision of the Executive Committee at their meeting in April, 1983, the amount of advertising in the journal had been increased, which would bring in additional revenue. The Editor-inChief appealed to members to take out personal subscriptions to the journal (taking advantage of the membership benefit of a $50 \%$ reduction in price), and also asked members to encourage their local and national pharmaceutical companies and other interested organisations to advertise in Diabetologia. If sufficient advertising revenue could be generated, there was a small possibility that the annual subscription rate might be lowered in the future.

To applause, the President thanked Dr. Berger for his excellent presentation and for all the effective arrangements and negotiations which he had handled since assuming the office.

\section{Annual subscriptions}

The Honorary Treasurer said that the main source of income of the Association was from the annual subscriptions paid by the Active and by the Supporting and Associate Members. Figure 1 showed the total subscription income compared with total administrative expenses over the past 6 years, with projections for the current year and for 
1984. The action taken by the General Assembly in raising subscriptions as from 1 January 1982 had resulted for the first time for some years in a small surplus against the administrative expenditure. However, as members would see, the projections for 1983 and 1984 indicated a worsening situation. Whilst the Association should break even in the current year, the increased expenditure to which he had referred in his earlier report projected a mounting deficit which would be increasingly difficult to combat unless action was taken now.

The Council therefore recommended that the annual subscriptions for Active Members over the age of 40 on the first of January in each year be raised to $£ 20$ (an increase of $33.33 \%$ ); and for those under the magic age of 40 , the subscription should be raised to $£ 15$ per year (an increase of $25 \%$ ). In addition, the Council recommended that those over retiring age, who had retired from active practice and yet still wished to continue their membership, should be required to pay an annual subscription equivalent to half the Active Member rate. It was recommended that these proposals be adopted to take effect as from 1 January, 1984

Dr. Krans confirmed that those members who had taken advantage of the facility to pay subscriptions in advance would not be required to increase their annual payments until their current subscription expired; and ended his statement by stating the Council's belief that if the General Assembly accepted the recommendations, the Association should be able to contain inflationary tendencies to an acceptable level.

The General Council approved the recommendations nemine contradicente.

\section{Elections}

Council Members, 1984-1987

The President reminded the General Assembly that Drs. Assal, Cerasi, Freychet, Katona and Waldhäusl were due to retire by rotation after the General Assembly in London in 1984. To succeed them, the Council had nominated: Dr. J.-P. Felber (Switzerland), Dr. V. A. Koivisto (Finland), Dr. H.Ørskov (Denmark), Dr. G. Panzram (East Germany), and Dr. G. Slama (France). The General Assembly approved their election.

\section{Honorary Treasurer}

The President reported that under the Constitution the term of office of the Officers was limited to 3 years. However, the Council recommended that the term of office of Dr. Krans as Honorary Treasurer be extended until 1987, to avoid the retirement in the same year of the Honorary Secretary and the Honorary Treasurer. Dr. Gepts pointed out that this did not create a precedent, since the General Assembly had allowed their first Honorary Secretary, Dr. Renold, to serve for 5 years.

The General Assembly approved the recommendation with acclamation.

\section{Honorary Auditors 1984-1985}

The President reported that neither Dr. Serrano-Ríos nor Dr. Standl was eligible for re-election. The Council therefore recommended the election of Dr. J. Ludvigsson and Dr. J.C. Nunes Correa as Honorary Auditors for the ensuing year, and this was approved by the General Assembly.

\section{Study Groups and Sub-Committees}

\section{Postgraduate Education Sub-Committee}

Dr. Serrano-Ríos paid tribute to the work of his predecessor as Chairman, Dr. J. J. Hoet. The Sub-Committee would be meeting during the present Annual Meeting to consider future activities. In the meantime, Dr. Serrano-Ríos was happy to report a successful EASD Postgraduate Course in Turkey which had been attended by 450 participants; and drew attention to the forthcoming Course in Cyprus.

Drs. Schliack and Skrabalo were due to retire by rotation in 1984, the other members being Drs. Koivisto, Menzinger and Tamas.

\section{Epidemiology Study Group}

Dr. J.H. Fuller reported that the 18th Annual Meeting of EDESG had been held in Gargnano, Italy in May, 1983. A Working Group, consisting of Drs. Jarrett and Teuscher, had been set up to draft recommendations to be made to the joint WHO/IDF Executive Committee in relation to the diagnostic criteria for diabetes with the aim of clarifying some of the ambiguities and difficulties in interpretation of the WHO proposals.

The 19th Annual Meeting was to be held in Austria in May, 1984, at the invitation of Dr. K. Irsigler.

Diabetes Pregnancy Study Group

Dr. D. R. Hadden reported that the 14th Annual Meeting of DPSG

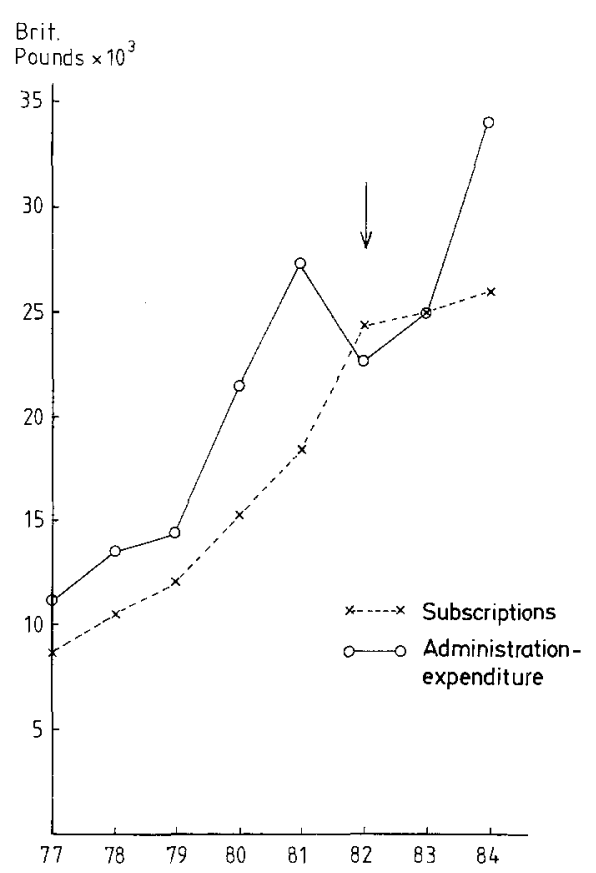

had been held in Leuven, Belgium just prior to the EASD Annual Meeting.

The 13th Annual Meeting had been held in Villars, Switzerland in August, 1982, and had been attended by 24 members and 45 guests. The topics selected for discussion had been gestational diabetes, and changes during diabetic pregnancy and their effect on fetal growth. The Jorgen Pedersen Memorial Lecture had been delivered by Professor J. M. Stowers.

Dr. Hamish Sutherland had retired from the Chairmanship of the Executive Committee, and had been succeeded by Dr. Hadden. The other members were Dr. A. van Assche and Dr. C. Hellerstrom.

The 15th Annual Meeting would be held in Belfast from 8-11 September 1984.

Diabetes Education Study Group

Dr. Assal reported that DESG had continued its activities in the field of diabetes education. The list of members had been updated, and now numbered nearly 600 persons. The number of centres in Europe where teaching is provided was 240 , which illustrated the continuing interest in the therapeutical approach to diabetes through the medium of patient education.

The Proceedings of the Second Symposium on Diabetes Education held in Geneva in 1982 had just been published, and included topics covered during the national Workshops held over the preceding 2 years in Geneva. Copies would be distributed to all members of DESG.

Five teaching letters were to be published annually, for distribution to all DESG members at two-monthly intervals.

Dr. Jean Canivet had retired by rotation, and his place as Vice-President had been taken by Dr. Henk Pelser, of Amsterdam.

In conclusion, Dr. Assal said that at the time of the creation of the Study Group three years earlier he had described it as being a newborn baby. With the help of so many European diabetologists and other members of the medical team, he felt justified in suggesting that they had now achieved adulthood.

\section{AIDSPIT}

Dr. Pfeiffer reported that the 2nd Workshop of the EASD Study Group on Artificial Insulin Delivery Systems, Pancreas and Islet Transplantation had been held at Igls, Austria in February, 1983. Amongst subjects discussed had been:

a) effect of improved glucose control on the development of diabetic microvascular complications;

b) insulin delivery systems and intensified conventional therapy;

c) registry of external insulin pumps;

d) pancreas and islet transplantation;

e) formulation and pharmacokinetics of insulin.

A summary of the findings of the Workshop would be published in Diabetologia in due course. 
The 3rd Meeting of the Study Group would be again be held in Igls, from 5-7 February 1984.

Nutrition Study Group

Dr. J.I. Mann reported that this Group was still in its infancy and had not yet formulated a Constitution. A very successful meeting had been held in Crete in May, 1983 on the subject of "Diabetes and Nutrition". The next Meeting would be held in Düsseldorf in 1984. Dr. Mann was presently acting as Co-ordinator.

\section{Lipoproteins Study Group.}

Dr. D.J.Galton, Chairman of the Study Group' reported that 20 interested members had met in Oslo on the previous day, during which a preliminary constitution had been discussed and agreed. The first scientific activity of the Group would be a meeting held at St. Bartholomew's Hospital, London on 11 September 1984, when the possibilities for collaborative studies would be considered. Details of the meeting would be published in Diabetologia. It was hoped that future meetings might be arranged in conjunction with the European Atherosclerosis Group as well as the European Lipoprotein Club.

The other Officers of the Study Group were Dr. G.Crepaldi (ViceChairman) and Dr. D. Pometta (Honorary Secretary).

\section{Any other business}

\section{Registration fees}

To applause, Dr. Pfeiffer raised the question of the increasingly high cost of registration fees for the Annual Meetings and expressed concern at the heavy burden which these represented for those for whom the fees were a personal responsibility. He questioned whether the inclusion of lunch was necessary, since many were able to enjoy the free facilities offered by the pharmaceutical companies. He also suggested that the timing of meetings might be re-considered so that use could be made of student dormitories in University vacation times.
The General Assembly agreed that these matters should be referred to the Council for further consideration.

Handing over of the presidency

Before handing over the Presidency of the Association, Dr. Gepts said that he wished to express the thanks of the General Assembly to the retiring members of the Council, Drs. Sönksen, Taljedal and Valverde for their services; and to extend a warm welcome to Drs. Luyckx, Tattersall, Standl and Wahren as new members of the Council.

Dr. Gepts said that he would also like to take this opportunity to express his warm personal thanks to the Officers and members of the Council with whom he had served for their constant help and encouragement.

To applause, Dr. Gepts then handed over the Presidency of the Association to Professor D. Andreani.

To prolonged applause, Dr. Andreani paid tribute to the quiet yet masterful guidance which Professor Gepts had given to the Association during the past 3 years.

Continuing, the President expressed his best thanks for the high honour which the Association had paid him, which he stressed was not for his personal merits, but a tribute to his country of origin. Reminding members of the distinguished colleagues in whose footsteps he followed (Drs. J.P. Hoet, F. G. Young, K.Lundbaek, W.Creutzfeldt, A. E. Renold, P. J. Randle and W. Gepts) he assured the General Assembly that he would do his utmost to uphold the dignity and authority of both the Office and the Association. In a light-hearted vein, he showed a slide listing his HLA typing, and ended by stressing that he would always welcome advice and constructive comment from the membership.

\section{Agenda for the 20th General Assembly of the European Association for the Study of Diabetes, to be held in Session Hall A, Barbican Centre, City of London, England, on Friday, 14 September 1984 at 5.30 p.m.}

\section{Opening Remarks \\ 2. Minutes, 19th General \\ Assembly, Oslo, 1983}
3. Reports
a) President
b) Honorary Treasurer
c) Honorary Auditors
d) Honorary Secretary

The President

Printed in Diabetologia (1984)

Vol. 27, No. 2

To be confirmed as a correct record

\author{
Dr. D. Andreani \\ Dr. H.M.J. Krans \\ Drs. J. Ludvigsson and J. Nunes \\ Correa \\ Dr. K.G.M. M. Alberti
}

\author{
e) Editor-in-Chief, Diabetologia \\ 4. Elections \\ a) Honorary Secretary \\ 1985-1988 \\ b) Council Members 1985-1988
}

c) Honorary Auditors 1984-1985

5. Siudy Groups

6. Any other business
Dr. M. Berger

In place of Dr. K. G. M. M. Alberti In place of Drs. J.-P. Assal, E. Cerasi, P. Freychet, G. Katona and W.K. Waldhäusl

To elect

To receive reports 